\title{
DETECTION OF STRUCTURAL CHANGES IN CONCRETE USING EMBEDDED ULTRASONIC SENSORS BASED ON AUTOREGRESSIVE MODEL
}

\author{
Joyraj CHAKRABORTY ${ }^{1}$, Andrzej KATUNIN ${ }^{2}$ \\ ${ }^{1}$ NeoStrain Sp. z o.o., Lipowa 3, 30-702 Kraków, Poland, e-mail: joyraj@neostrain.pl \\ ${ }^{2}$ Institute of Fundamentals of Machinery Design, Silesian University of Technology, Konarskiego 18A, \\ 44-100 Gliwice, Poland, e-mail: andrzej.katunin@polsl.pl
}

\begin{abstract}
Embedded ultrasonic transmission measurements can be a cost effective and more user-friendly alternative in comparison to commonly used structural health monitoring systems used in civil engineering to detect operational or environmental changes in structure. They can be used to detect small structural changes in large concrete structures without necessity of placing a sensor on the spot where the changing is taking place. This paper presents the investigations on the possibility of utilising autoregressive model, where the velocity of ultrasonic wave in a medium is dependent on the operational state. The goal is to use the model for localization of operational changes in the large concrete structure by means of embedded ultrasonic transducer networks. In this study, several static load tests and dynamic test on large reinforced concrete beams have been performed using embedded ultrasonic sensors. Using the autoregressive model it is possible to localize operational changes in the concrete structure. The proposed approach of diagnostic signal processing allows for precise evaluation of structural changes in concrete.
\end{abstract}

Keywords: Structural Health Monitoring, Reinforced concrete, Bridge, Ultrasonic inspections, AR model

DETEKCJA ZMIAN STRUKTURALNYCH W BETONIE Z WYKORZYSTANIEM WIELU
CZUJNIKÓW ULTRADŹWIĘKOWYCH NA PODSTAWIE MODELU AUROGEGRESYWNEGO

\begin{abstract}
Streszczenie
Zintegrowane ultradźwiękowe pomiary transmisyjne mogą być efektywną pod względem kosztów i bardziej przyjazną dla użytkownika alternatywą w odniesieniu do często stosowanych systemów monitorowania stanu struktur w budownictwie w celu detekcji eksploatacyjnych lub środowiskowych zmian strukturalnych. Mogą one być wykorzystane przy detekcji minimalnych zmian w dużych strukturach betonowych bez konieczności umieszczenia czujnika w lokalizacji występującej zmian. Artykuł przedstawia wyniki badań w zakresie możliwości zastosowania modelu autoregresyjnego, gdzie prędkość fali ultradźwiękowej w medium jest zależny od stanu eksploatacyjnego. Celem jest zastosowanie modelu do lokalizacji zmian eksploatacyjnych w dużej betonowej strukturze, wykorzystując sieci zintegrowanych przetworników ultradźwiękowych. W niniejszej pracy monitorowano statyczne i dynamiczne testy dużych zbrojonych betonowych belek $\mathrm{z}$ wykorzystaniem wbudowanych czujników. Stosując model autoregresyjny, możliwe było zlokalizowanie zmian eksploatacyjnych w betonowej strukturze. Zaproponowane podejście diagnostycznego przetwarzania sygnałów pozwala na dokładną oceną zmian strukturalnych w betonie.
\end{abstract}

Słowa kluczowe: monitorowanie stanu konstrukcji, beton zbrojony, most, badania ultradźwiękowe, model AR

\section{INTRODUCTION}

Concrete is the most used material in volume in the world for many civil infrastructures, like bridges. They are capable of safely transferring the superimposed loads to the foundations; however, their structural integrity is degraded by different kinds of operational and environmental effects. Therefore, their strength is important as a civil infrastructure assign a significant portion of the national economy, so keep a high level of structural safety, durability, an efficient system is urgently required for regular structural assessment and performance of the infrastructure. For such purpose, monitoring with the use of low-cost distributed sensors is an effective solution [1].

Various methods called Non-Destructive Testing (NDT) techniques have been used for many years, and in many cases combined with Structural Health Monitoring (SHM), and more than seventy types of standardized testing methods can be found [2]. Although some of them have potential applicability in the considered problem, they are widely used. Indeed, NDT techniques using devices with attached sensors have some drawbacks: the necessity of huge number of connections, small coverage place, bulky size, complex signal processing, and quite strong local mechanical noises initiated by the sensor elements. For 
example, strain gauges are commonly used as lowcost measurement devices to measure the internal stress/strain in concrete structures. The problem of application of traditional strain gauges is the difference value of stress inside a concrete specimen, and at a point on the surface of the specimen under axial loading. Also, fiber optic [3] and piezoelectric sensors [4] have shown a good performance in measuring internal stresses. The main disadvantages are their cost and capability for long-term monitoring. Another most used set of NDT techniques for reinforced concrete inspection is acoustic and Ultrasonic Pulse Velocity method (UPV). UPV method is based on sending and receiving sound waves inside the cement matrix. The measured parameters are the elastic properties of the material.

During decades, ultrasonic methods are widely used in civil engineering to detect crack initiation and growth, defects as well as to determine material properties. Traditional ultrasonic inspection shows a few important disadvantages. The first one is the need of trained operator, which is sometime difficult in practice. The high influence of surface by soft material and external environmental effects (changes in temperature, wind and others) leads to undesirable effects on the sensing accuracy. The transducers are intending for accidents or impairment during practical field measurements. Therefore, BAM (Bundesanstalt für Materialforschung und -prüfung) developed a novel ultrasonic transducer, which can be permanently embedded in concrete [5]. The new ultrasonic data evaluation has to follow for detecting subtle changes (e.g. velocity changes) in materials. The main benefit of this sensor is a high sensitivity on monitored large areas of a structure with a limited number of sensors.

Since acquired signals from the mentioned sensors need to be analyzed in order to collect diagnostic information on a diagnosed object, it is essential to use primary signal processing methods and approaches. From a variety of data evaluation approaches for collecting structural diagnostic information, UPV mostly uses the first arrival, time delay, Hilbert transform of ultrasonic wave [6-9]. Unfortunately, the sensitivity of this technique is limited, as quite low frequencies $(20-100 \mathrm{kHz}$ relates to a wavelength in concrete) must be used due to the natural scattering properties of concrete, and ultrasonic wave received by the receiver/transducer is not only peaks, also it contains a lot of noise components.

As infrastructures become larger and more complicated, examination and localized methods become inefficient, hence more primary effective methods are needed. Recently, Autoregressive Model (AR), a technique adapted from mechanical vibration, was introduced to civil engineering experiments. It is based on the comparison of past behavior, when there is some correlation between values in a time series. The theoretical relationship between structural operational changes and AR coefficients are investigated from response signals [10]. An overview on applications of AR models can be found in [11].

In this paper, at first, the literature review of propagation of ultrasonic wave in concrete is presented, then the autoregressive model is used for evaluation of signals acquired from ultrasonic sensors, and based on the velocity changes of the ultrasonic waves induced by operational effects, the changes in concrete were determined. This study is part of the INFRASTAR project, dealing with advanced monitoring and NDT techniques for pressure, temperature, and strain measurements and fatigue damage assessment. The project aims are to get benefit from novel sensors and improved data processing methods to "smart" the structures.

\section{ULTRASONIC NON-DESTRUCTIVE EVALUATION METHODS}

\subsection{Fundamentals of the propagation of ultrasonic waves}

UPV testing is based on time-varying sending and receiving ultrasound pulse waves in structure. It can be used in many applications for damage detection/evaluation, source localization, material characterization, and more. Ultrasonic inspection method consists of high-frequency sound waves which are normally above $20 \mathrm{kHz}$ frequency introduced into the material. At least two transducers to perform the ultrasonic inspection are necessary: one transmitter and one receiver. There are three basic ways in which the transducers can be placed: direct, semi-direct, and indirect. A signal pulse generator and amplifier is used to produce an amplified electric signal, then it is converted to mechanical vibrations by a piezoelectric crystal transducer, and transmitted through the structure. Then, a reflected wave is received by the receiver and converted back to an electric signal which is called an echo $[12,13]$. In the ultrasonic inspection, the most commonly used modes are longitudinal and shear waves for the propagation. For concrete inspection, ultrasonic pulse velocity method $[5,12]$ is a useful and versatile NDT method for structure. Based on the velocity of propagation of ultrasound waves, it is possible to evaluate the quality of concrete. Ultrasonic pulse velocity method can be used for evaluation of the similarity, the position of damage or deepness inside both reinforced or masonry structures. To predict the strength of concrete, measurements of the Rayleigh wave and the skimming longitudinal wave velocities are used [14]. The speed of sound is different in various materials, since the mass of the atomic particles and the elastic properties are different for various materials. The mass of the atom is related to the thickness of the material, and the elastic properties are related to the elastic constants of the material. For longitudinal waves, the speed of the sound in solid material like concrete is given in (1) [15]: 


$$
V_{l}=\sqrt{\frac{E(1-n)}{\rho(1-n)(1-2 n)}},
$$

the velocity of surface Rayleigh waves is given by:

$$
V_{r}=\frac{0.87+1.12 n}{1+n} \sqrt{\frac{E}{2 \rho(1+n)}},
$$

where $V_{l}$ and $V_{r}$ is the velocity of sound for longitudinal wave and Rayleigh waves, $E$ is the young modulus, $\rho$ is the material density, and $n$ is the Poisson's ratio. Equations (1) and (2) relate wave velocities with elastic parameters. Therefore, the propagation of wave is strongly affected by the elastic properties and density of constituent materials [16]. Since elastic waves in concrete are tend to diffraction and attenuation, the elastic waves of relatively low frequency (as low frequency has a large wave-length), and the high energy source is usually needed $[7,14]$. If the wave frequency is lower than $20 \mathrm{kHz}$, the wavelength is larger than the distinguishable size of the structure. It is easy to implement the technique for the structural health monitoring and transient dynamic analysis in this frequency range [7]. If the frequency is megahertz rage (higher than $1 \mathrm{MHz}$ ), it is difficult to observe ultrasonic pulse waves on a large length scale, because of the combination of scattering and attenuation. In this case, ultrasonic techniques could be used only on small size specimen in the laboratory [17]. The parameters that impact on the velocity and attenuation of stretch of ultrasound waves are $[7,18]$ : the nature of the load; the age of the concrete (the velocity increases with the time of the concrete); the form and the volume of the structure; the presence of steel reinforcements (the speed increases in proximity of the steel bars); the water/cement ratio; environmental effects, e.g. humidity and temperature of a concrete [17].

The compressive strength of lightweight concrete (84 different compositions were tested between 3 to 180 days) is investigated using UPV method [19,20]. Three types of lightweight aggregates (Leca and Argex from Portugal and Arlita from Spain) were examined. The influences of the cement type and content, amount of water, type of admixture, initial wetting conditions, type and volume of aggregate were examined. The highest velocities were realized in samples containing high cement content and low watercement ratio. Both ultrasonic signal velocity and compressive strength increase over the 90-day curing period. The compressive strength of lightweight concrete (LWC) and velocity of ultrasonic signal reduce when the size of aggregate increases. However, the ultrasonic signal velocity increases in common thickness concrete and ages in LWC with Leca, but less measurable in LWC with Arlita [20]. According to this result, different wetting conditions do not have a strong influence. As ultrasonic inspection for concrete that has been developed and evaluated in the laboratory are being transitioned to field operation, the influence of operational changes in real structure is becoming of growing concern [21]. One major methodology for addressing this problem is to develop features that are sensitive to operational changes and damages $[21,22]$. Since it is hard to detect operational and environmental changes from one single feature, the approach generally taken is to develop features for a particular object and evaluate their operational changes.

\subsection{AR time series model}

Linear time series models have been used in such a damage detection process that includes applications to a wide range of structures and associated damage scenarios, including cracking in concrete columns [18,21], loose connections in a bolted metallic frame structure [22], or damage to insulation on wiring [23]. However, the linear nature of such a modeling approach limits the scope of application and the ability to accurately assess the condition of systems that exhibit nonlinearity in their undamaged state. The AR model may be used as a changes/damage feature extractor for the ultrasonic test. This AR model approach consists of using the parameters estimated from the baseline conditions, and calculating the response of data obtained from the structure. This AR model can be written as:

$$
\varepsilon(t)=x(t)-\sum_{i=1}^{n} \alpha_{i} \bar{x}(t-i)+e_{m},
$$

where $x(t)$ is the measured signal at discrete time index $t$, and $\bar{x}$ is the predicted signal value. The residual error $\varepsilon(t)$, which is the difference between the measured and predicted signal, is calculated at time $t . e_{m}$ is a noise that follows a normal distribution with zero mean and variance $\sigma^{2}$, and is independent of the past time series $\bar{x}$. $n$ is a model order. The coefficients of the AR model parameter $\alpha_{i}$, can be estimated by using Akaike's information criterion (AIC) or Root Mean Squared Error (RMSE) [22,24]. To estimate the correct AR model parameter, it is necessary to know the physical mechanisms underlying the system. RMSE will be a good choice to compute optimal model parameter from elastic properties of concrete, as it is easy to compute and more generally, minimizing RMSE finds an approximation for the conditional prospective value of the next observation. In this paper, RMSE is used to find an optimum model order:

$$
\operatorname{RMSE}(\alpha)=\frac{1}{n} \sqrt{\varepsilon(t)} .
$$

The estimation of the AR model order can be realized by minimizing the RMSE value using (5).

The most important step to find an optimum model order is to remove the noises from the data set. Nevertheless, in many cases equal RMSE value cannot achieve the optimum model order. Dimensionality reduction technique is used to remove noisy and redundant features (e.g. 
crosstalk) until reaching an appropriate model order to adopt the underlying physical system response correctly (Fig. 1). However, the average of RMSE values can be used to characterize model performance in the validation period as well as to compare the outputs to a perfect match between predictions and the measured signal. An example of ultrasonic signals presented in Figs. 2 and 3 shows the effect of high-order $\left(25^{\text {th }}\right.$ order $)$ and low-order $\left(8^{\text {th }}\right.$ order) models to resemble the signal. The diamond line represents the real signal $x(t)$, which is chosen as the reference signal, and the solid line (with no markers) represents the predicted signal $\bar{x}$ with the high model order in Fig. 2(a), and low model order in Fig. 2(b), respectively. In Fig. 3, the first plot indicates that the real signal and low model order estimated signal are less correlated, while the high peak in the second plot indicates that model is highly correlated to the signal (time shift $=0)$.

$$
\text { RMSE }=\sqrt{\frac{\sum_{i}^{n}\left(X_{\text {measured }, i}-X_{\text {model }, i}\right)^{2}}{n}} .
$$

The flow chart of modeling stage of AR algorithm is shown in Fig. 1 .

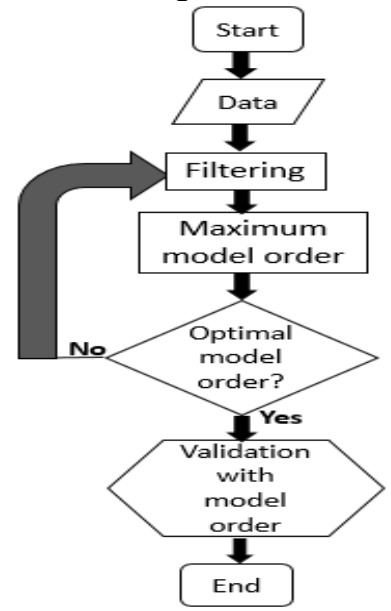

Fig. 1. Flowchart of modelling stage of AR algorithm

AR models work especially fair well when modelling the feedback of linear, time-invariant systems. AR method delivers the best linear fit to the measured signal if the operational changes are nonlinear, but there is uncertainty when the system is suppressing to other inputs then there is no guarantee that this model will exactly compute the responses.

\section{EXPERIMENTAL PROCEDURE}

\subsection{Test object}

A first-class infrastructure is an inevitable factor for economic growth. Bridges have a key position in this infrastructure system. Its functional failure or collapse has significant economic and financial consequences. For this reason, it is important to regularly monitor the current bridge condition, and derive estimates of the remaining service life. This ensures a safe and economically sensible use for existing structures. For this purpose, BAM develops a structure shown in Fig. 4 called BLEIB structure (Shared object for INFRASTAR project) at Horstwalde that includes experimental studies such ultrasound for the detection of operational changes or cracks. The structure is $25 \mathrm{~m}$ long with three supports, and 5 cross sections. The load cell is installed on the front bridge side (fixed anchor) on the tendons during their initial installation, and supplemented by a spherical cap and steel plates.

a)

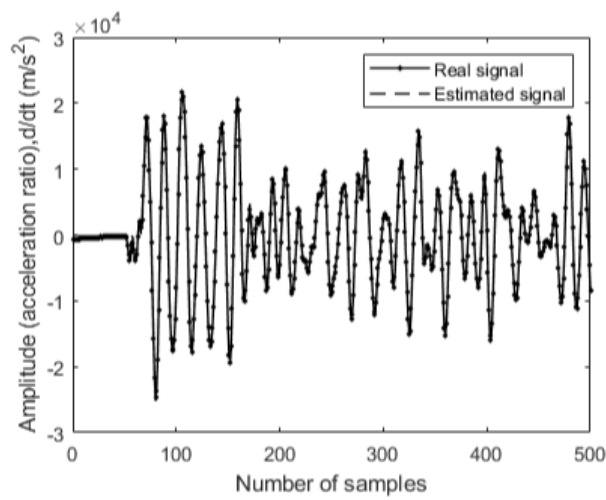

b)

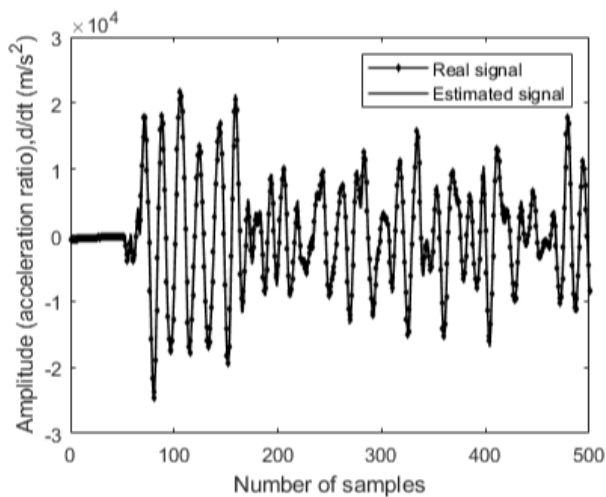

Fig. 2. High (a) and low (b) model order estimated AR model (all ultrasonic signals are acceleration data in arbitrary units)

\subsection{Experimental setup}

Fourteen ultrasonic transducers were embedded in the structure during construction. They become vertically mounted on the stirrup reinforcement. They are controlled by an external BAM data acquisition system. This data acquisition system conducts a transmission pulse successively to each of the transducers, while the other waves passing through the structure to register in receiver ultrasonic transducer and store it in the local system, e.g. transducer pair 1 and 2, where transducer 1 sends the pulse and transducer 2 receives the response, respectively. The setup is divided into sections as shown in Fig. 5 and Table 1. Parameters are derived from the ultrasound signals (e.g. Ultrasonic velocity changes), from which one can draw conclusions about the temporal change of the elastic parameters or (micro) cracking in the influence area of changes. Two kinds of test were performed to locate changes in the structure, static and dynamic tests equipment shown in Fig. 6. 

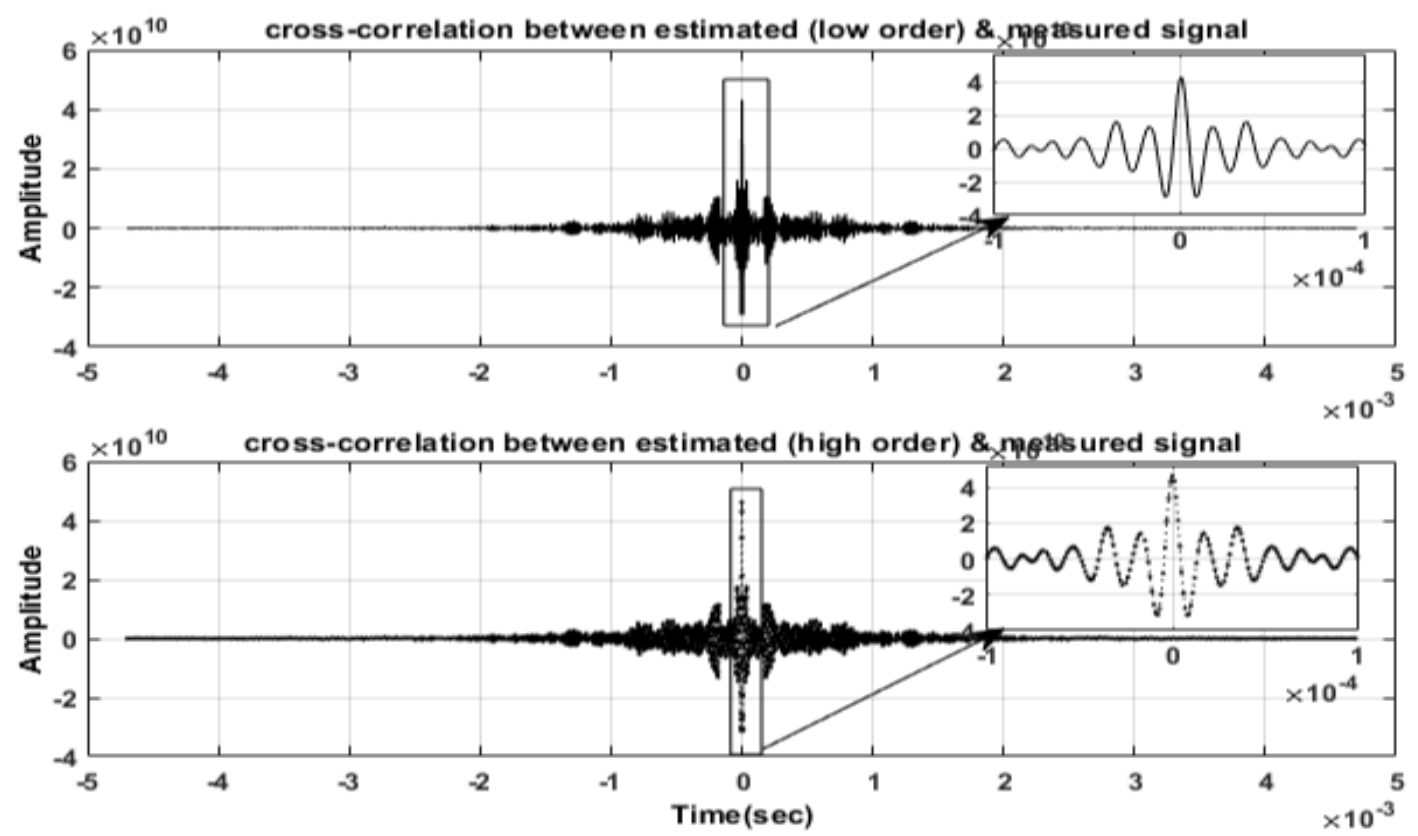

Fig. 3. Cross-correlation of real signal $x(t)$ to the estimated signal $\bar{x}(t)$

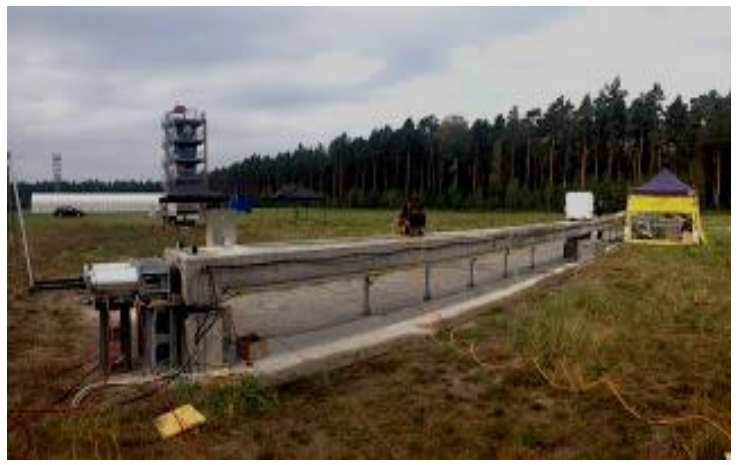

Fig. 4. BLEIB Structure at Horstwalde, Berlin

\section{ANALYSIS OF RESULTS}

\subsection{Results of measurements}

The order of the AR model is an important, but unknown value. A high order may perfectly resemble the data, but the model will not generalize to other data sets. Contrary, a low order will not adopt the underlying physical system response correctly. In order to find out the optimum model order, RMSE is used. For the purpose of finding the optimum AR model, the RMSE is plotted as a function of the model order. The estimation of the AR order can be achieved by minimizing the RMSE value. Fig. 7 shows the RMSE of AR models of increasing order (from 1 to 100) for emitter 13 and receiver 14 .

The results suggest that an AR model of order $\alpha=5$ would fit the data sets well. After the parameters have been estimated for both AR model, Figs. 8 and 9 show how well the model fits the measured and estimated ultrasonic signal-time histories at emitter 13 and receiver 14 for the dynamic and static test using the AR model $(\alpha=5)$.
From a qualitative point of view, the measured and estimated ultrasonic signal (first 500 samples from Fig. 8) shown in Fig. 9.
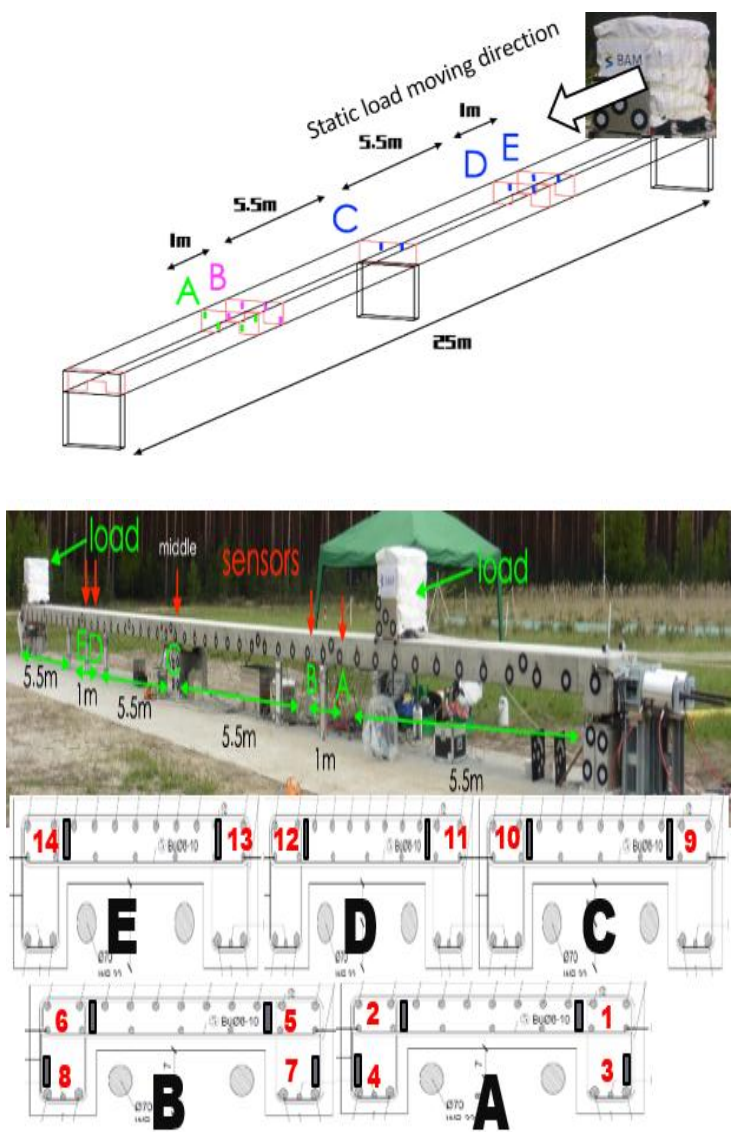

Fig. 5. A scheme of sensor positioning at BLIEB structure, and its view with main dimensions and loading 

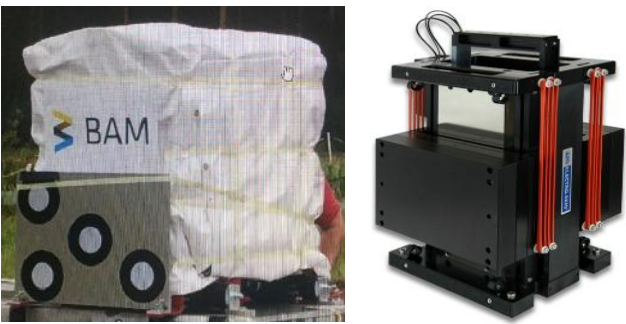

Fig. 6.4 tons load for the static test, and the shaker for the dynamic test

\begin{tabular}{|c|c|}
\multicolumn{2}{c}{ Table 1. Sensor positions } \\
\hline Section & Sensor Number \\
\hline A & Sensor $1 \& 2$; Sensor $3 \& 4$ \\
\hline B & Sensor 5 \& 6; Sensor $7 \& 8$ \\
\hline C & Sensor $9 \& 10$ \\
\hline D & Sensor $11 \& 12$ \\
\hline E & Sensor $13 \& 14$ \\
\hline
\end{tabular}

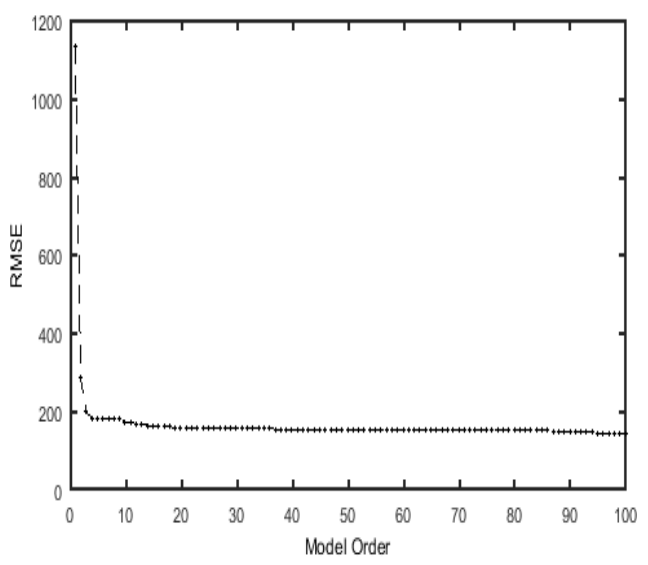

Fig. 7. RMSE of AR model

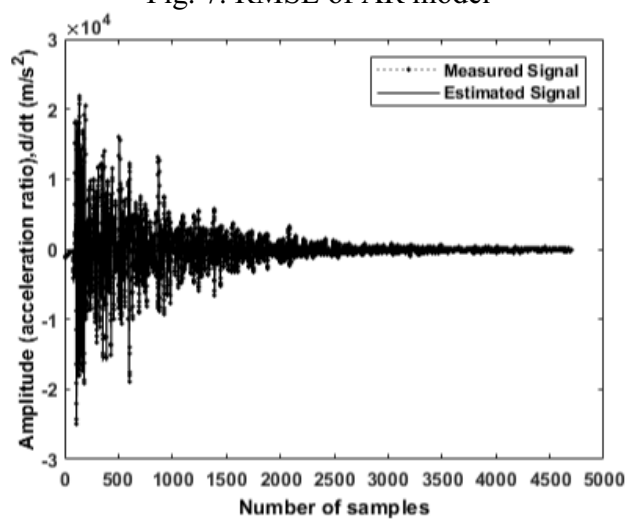

Fig. 8. Comparison of the measured and estimated ultrasonic signal using the AR $\operatorname{model}(\alpha=5)$

\subsection{Determination of structural changes}

For dynamic test, $30.6 \mathrm{~kg}$ shaker was placed in the structure (near to sensor positions 5 - 6). During the dynamic test, $2 \mathrm{~Hz}$ to $60 \mathrm{~Hz}$ random frequency applied for the first 15 minutes on the structure. For the static test, a load of $39.85 \mathrm{kN}(2 \mathrm{x} 19.6 \mathrm{kN})$ was moved in various steps from one side to another side of the structure (52 minutes $<\mathrm{t}<140$ minutes), static load was applied from the right top side of the structure (Fig. 5). Time and position of static loads are shown in Fig. 10. The applied loads, even very small moves, had a clear influence on the ultrasonic signals. The normalized residual errors are used to find the correlation or the presence of periodic velocity under the different operational effects if the signals buried under noise also. The average velocity changes due to static load per step during the load moving stepwise. The velocity only partly recovered after a pause, probably due to no operational effects during these periods. The result of the residual errors coefficient from AR model $(\alpha=5)$ is shown in Fig. 11. Notice that the residual errors are estimated from dynamic and static test time history from emitter 13 and receiver 14 . The plots show that the resulting residuals from the AR model $(\alpha=5)$ are correlated, because it is still possible to identify the dynamic and static changes in the structure. The residuals are increasing up to a maximum value when the static load is applied on top of the sensor ( $t=75$ minutes), which is comparable $(t=19$ minutes and static load position 19 meter on the structure) with the Fig. 11. Even load is passing through the sensor pairs 13-14 $(t=85$ minutes), small pause, and when the static load far from sensor pair positions 13-14 can be clearly observed (Fig. 11).

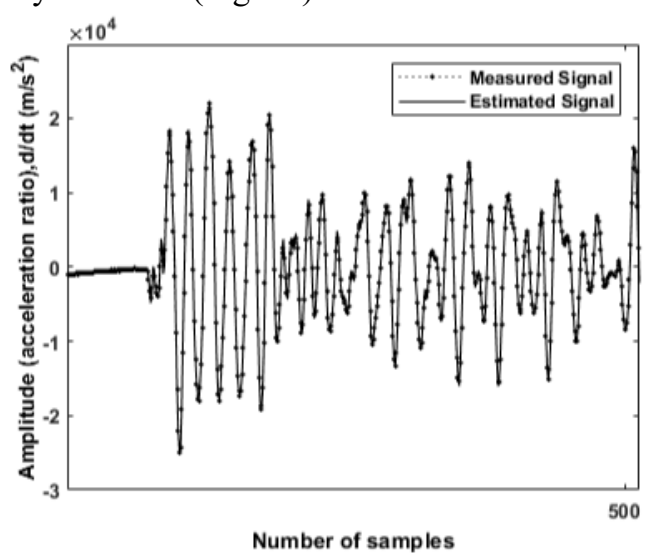

Fig. 9. Comparison of the measured and estimated ultrasonic signal of the first 500 samples

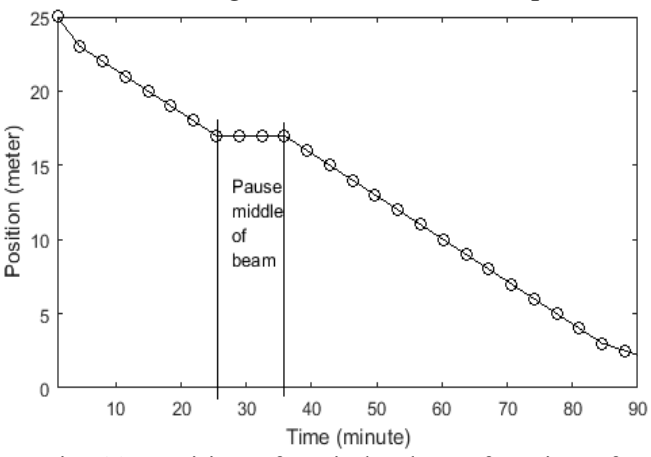

Fig. 10. Position of static load as a function of time

In the AR model $(\alpha=5)$, the changed states are split into two groups in order to highlight the influence on the AR residuals of the dynamic and static effects. Fig. 11 suggests that increasing the level of nonlinearities in the operational change states in the structure tends to decrease the 
amplitude of the parameters. The AR parameters were calculated by fitting the AR model to a signal from one transducer pair (emitter 13 , receiver 14) of static and dynamic state condition using the RMSE technique. To better clarify those changes, Fig. 12 shows the model $(\alpha=5)$ parameter for dynamic test conditions at emitter 13 , receiver 14 sensors. The impact is weak comparing to the static loads. As the expected changes in the structure are small compare to $39.85 \mathrm{kN}$ static load.

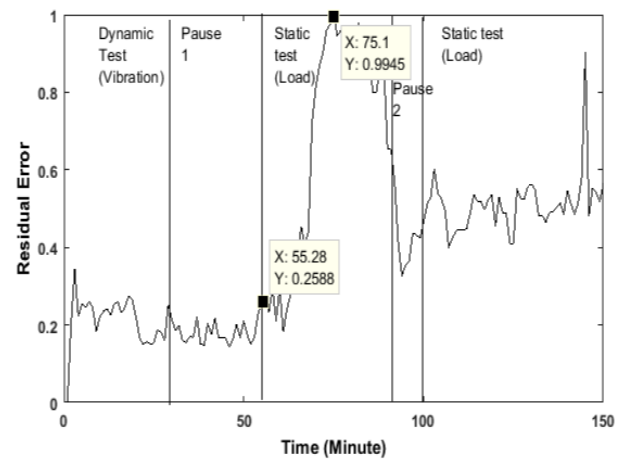

Fig. 11. Residual error coefficient of ultrasonic time histories

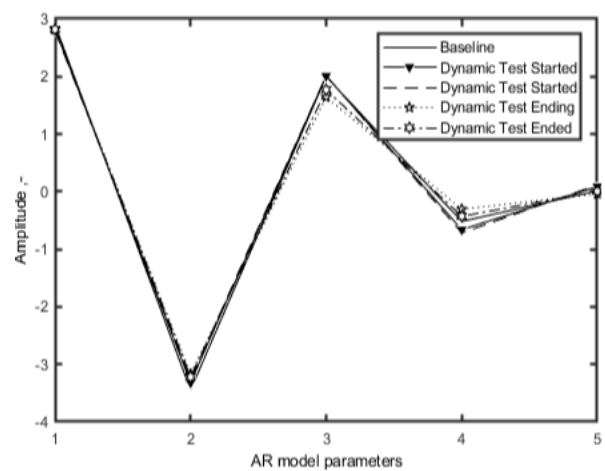

Fig. 12. AR model $(\alpha=5)$ parameters for dynamic state conditions

However, the amplitude of the damaged or changed states with amplitude variations has no correlation with the level of damage or changes in the structure. These results suggest that the operational and environmental variations can introduce changes in the structural response and mask the responses related to damage. This fact makes the discrimination of the damaged states challenging with operational and environmental variations from all the undamaged states.

\section{CONCLUSIONS AND FUTURE WORK}

The embedded ultrasonic transducers in the concrete structure have shown to be valuable devices for various tasks in long-term SHM. AR residual error appears to be the potential changes/damage-sensitive feature. The source of changes in the structure seems to induce changes in those AR parameters related to the level of changes in the structure. Load changes can be detected and localized and, therefore, this feature can also be used to evaluate the severity of damage. Damage or change introduces strong correlation in the $\mathrm{AR}$ residual errors. However, the correlation with the level of change seems to disappear when the damage is present with operational and environmental variations.

Since this paper is a part of our work in progress, we can briefly list some of the parameters that we want to incorporate in our next phase of testing. First of all, the number of sensors that are used in the localization as well as the influence of the distance between the sensors, has not been considered. Secondly, we plan to do some preprocessing on the ultrasonic signal before feature extraction from the ultrasonic signal. Digital noise reduction (with oversampled signals) and classification can improve the localization accuracy. Thirdly, the multiple feature based sensor fusion for the source or damage localization will have to be investigated as well.

\section{ACKNOWLEDGMENTS}

The authors wish to acknowledge the help of Dr. Ernst Niederleithinger and Xin WANG at BAM for the sensors and test in BLEIB structure. The project INFRASTAR (infrastar.eu) has received funding from the European Union's Horizon 2020 research and innovation programme under the Marie Skłodowska Curie grant agreement No 676139. The grant is gratefully acknowledged. The authors would like to extend a special thanks to Dr. Hakim Ferria for the management of the project.

\section{REFERENCES}

1. Ceylan H. Use of smart sensor systems for health monitoring of the transportation infrastructure system. In proceedings of the 3 rd international conference on transportation infrastructure, Pisa, Italy. 2014: 22-25.

2. Yanhua S, Yihua K, Chen Q. A new NDT method based on permanent magnetic field perturbation. NDT \& E International. 2011; 44(1): 1-7. https://doi.org/10.1016/j.ndteint.2010.01.007

3. Deng L, Cai CS. Applications of fiber optic sensors in civil engineering. Structural Engineering and Mechanics. 2007; 25(5): 577-596. https://doi.org/10.12989/sem.2007.25.5.577

4. Yu X, Kwon EA. Carbon nanotube/cement composite with piezoresistive properties. Smart Materials and Structures. 2009; 18(5): 055010. https://doi.org/10.1088/0957-4484/20/44/445501

5. Niederleithinger E, Wolf J, Mielentz F, Wiggenhauser H, Pirskawetz S. Embedded ultrasonic transducers for active and passive concrete monitoring. Sensors. 2015; 15(5): 9756-9772. https://doi.org/10.3390/s150509756

6. Birks AS, Green RE, McIntire P, Eds. The nondestructive testing handbook, Vol. 7. Ultrasonic Testing, $2^{\text {nd }}$ ed. Columbus, OH: American Society for Non-Destructive Testing; 1991.

7. Fröjd P, Ulriksen P. Frequency selection for coda wave interferometry in concrete structures. 
Ultrasonics. 2017; 80(1): 1-8.

https://doi.org/10.1016/j.ultras.2017.04.012

8. Marioli D, Narduzzi C, Offelli C, Petri D, Sardini E, Taroni A. Digital time of flight measurement for ultrasonic sensors. IEEE Transactions on Instrumentation and Measurement. 1992; 41(1): 9397. https://doi.org/10.1109/19.126639

9. Grennberg A, Sandell M. Estimation of subsample time delay differences in narrowband ultrasonic echoes using the Hilbert transform correlation. IEEE transactions on Ultrasonics, Ferroelectrics, and Frequency Control. 1994; 41(5): 588-595.

https://doi.org/10.1109/58.308493

10. Nair KK, Kiremidjian SA, Law HK. Time seriesbased damage detection and localization algorithm with application to the ASCE benchmark structure. Journal of Sound and Vibration 2006; 29(1): 349368. https://doi.org/10.1016/j.jsv.2005.06.016

11. Li WK, Tong H. Time series: advanced methods. International Encyclopedia of the Social and Behavioural Sciences. 2001:15699-15704. https://doi.org/10.1016/B0-08-043076-7/00523-4

12. Larose E, Obermann A, Digulescu A, Planes T, Chaix JF, Mazerolle F, Moreau G. Locating and characterizing a crack in concrete with diffuse ultrasound: A four-point bending test. The Journal of the Acoustical Society of America. 2015; 138(1): 232-241. https://doi.org/ 10.1121/1.4922330

13. Bogas AJ, Gomes MG, Gomes A. Compressive strength evaluation of structural lightweight concrete by non-destructive ultrasonic pulse velocity method. Ultrasonics 2013; 53(5): 962-972. https://doi.org/10.1016/j.ultras.2012.12.012

14. Wu TT, Liu PL. Advancement on the nondestructive evaluation of concrete using transient elastic waves. Ultrasonics. 1998; 36(1): 197-204. https://doi.org/10.1016/S0041-624X(97)00096-6

15. Krautkramer J, Krautkramer H. Ultrasonic Testing of Materials, $4^{\text {th }}$ ed. Berlin, Heidelberg: Springer; 1990. https://doi.org/10.1007/978-3-662-02296-2

16. Grêt AA, Snieder R, Scales J. Time-Lapse monitoring of rock properties with coda wave interferometry. Journal of Geophysical Research: Solid Earth 2006; 111(B3): 0148-0227. https://doi.org/10.1029/2004JB003354

17. Lu Y, Michaels EJ. A methodology for structural health monitoring with diffuse ultrasonic waves in the presence of temperature variations. Ultrasonics. 2005; 43(2): 717-731. https://doi.org/10.1016/j.ultras.2005.05.001

18. Fugate M, Sohn H, Farrar CR. Vibration-based damage detection using statistical process control. Mechanical Systems and Signal Processing. 2001; 15(4): 707-721. https://doi.org/10.1006/mssp.2000.1323

19. Kewalramani AM, Gupta R. Concrete compressive strength prediction using ultrasonic pulse velocity through artificial neural networks. Automation in Construction. 2006; 5(3): 374-379. https://doi.org/10.1016/j.autcon.2005.07.003

20. Michaels JE, Michaels TE. Detection of structural damage from the local temporal coherence of diffuse ultrasonic signals. IEEE Transactions on Ultrasonics, Ferroelectrics, and Frequency Control. 2005; 52(10): 1769-1782. https://doi.org/10.1109/TUFFC.2005.1561631

21. Sohn H, Czarnecki J, Farrar CR. Structural health monitoring using statistical process control. Journal of Structural Engineering. 2000; 126(11): 1356-1363. https://doi.org/10.1061/(ASCE)07339445(2000)126:11(1356)

22. Allen D, Sohn H, Worden K, Farrar C. Utilizing the sequential probability ratio test for building joint monitoring. Proc. SPIE 2002; 4704: 1-11. https://doi.org/10.1117/12.470707

23. Clark AG. Cable damage detection using time domain reflectometry and model-based algorithms. Lawrence Livermore National Laboratory 2008; document No. LLNL-CONF-402567.

24. Figueiredo E, Figueiras J, Park G, Farrar CR, Worden $\mathrm{K}$. Influence of the autoregressive model order on damage detection. Computer-Aided Civil and Infrastructure Engineering. 2011; 26(3): 225-238. https://doi.org/10.1111/j.1467-8667.2010.00685.x

Received 2018-07-27

Accepted 2018-12-14

Available online 2018-12-17

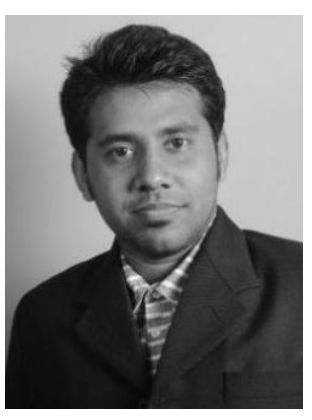

Joyraj CHAKRABORTY was born in Chittagong, Bangladesh. He received the BSc degree from the Daffodil International University, Dhaka, Bangladesh, the MSc degree from the Blekinge Institute of Technology, Sweden, in 2013, all in electrical engineering with emphasis on signal processing. $\mathrm{He}$ worked for KU Leuven, Belgium, and the University of Twente, Nederlands, from 2014 to 2017 , where he was involved in indoor acoustic localization and FBG sensor for asphalt systems. He is currently employed as a $\mathrm{PhD}$ candidate researcher in NeoStrain at Krakow, Poland. His current research interests include signal processing, intelligent control systems, ultrasonic and acoustic SHM systems.

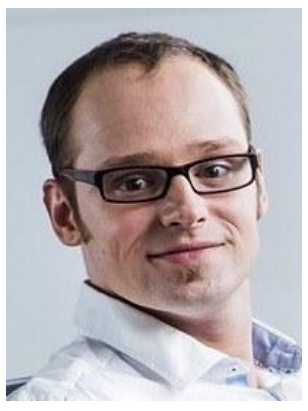

Andrzej KATUNIN received the BS degree in Mechanics from the Bialystok Technical University, Poland, in 2006, and his $\mathrm{MS}, \mathrm{PhD}$, and $\mathrm{DSc}$ degrees in Mechanics from the Silesian Technical University, Poland, in 2008, 2012, and 2015 , respectively. $\mathrm{He}$ is an associate professor on the research position in the Institute of Fundamentals of Machinery Design, Silesian University of Technology. His research interests include mechanics of composites with emphasis on fatigue and thermal effects, non-destructive testing methods, advanced signal and image processing techniques, wavelets and fractals theory and applications. 